\title{
Linking of Service Quality and Switching Costs with Turnover Intentions: The Mediating Role of Customer Loyalty

\author{
Muhammad Zakiy ${ }^{1, *}$ Muhsin Haryanto ${ }^{1}$
}

${ }^{1}$ Universitas Muhammadiyah Yogyakarta, Indonesia

*Corresponding author. Email: muhammad.zakiy@fai.umy.ac.id

\begin{abstract}
The development of Sharia Banks in Indonesia was exceedingly rejoicing in the early years of the establishment of the first Sharia bank, Bank Mumalat Indonesia, in 1992. This development was followed by many conventional banks spinning off into Sharia Banks. However, lately, the development of Islamic Banks in Indonesia has been discouragement. This can be seen from the market share of Islamic banks that have relatively no increase from year to year. Seeing this condition, researchers are interested in conducting research on the loyalty and switching intention of Bank Muamalat Indonesia customers, who are the first and pioneer of Sharia Banks in Indonesia. The purpose of this study is to look at the effect of Bank Muamalat Indonesia's service quality and switching cost on customer intention switching with loyalty as a mediating variable that can explain this effect. This research was conducted on Bank Muamalat Indonesia customers with a total sample of 168 respondents taken through convenience sampling and using SEM AMOS as a data analysis tool. The results of this study indicate that service quality and switching costs have a positive effect on loyalty, and loyalty has a negative effect on switching intention. In addition, loyalty can also fully mediate the influence of service quality and switching costs on switching intentions
\end{abstract}

Keywords: Bank Muamalat, Switching Intention, Switching Cost, Customer Loyalty.

\section{INTRODUCTION}

Bank Muamalat is the first Sharia Bank operating in Indonesia. Since it was founded in 1991 and started operating in 1992, Bank Muamalat has been able to demonstrate its existence and rapid development. The success of Bank Muamalat in the Indonesian banking industry made conventional banking begin to follow the successful steps of Bank Muamalat by opening its Sharia Business Unit (UUS). This can be seen from the majority of Sharia Banks, which initially became business units of Conventional Banks, have spin-offs into Sharia Commercial Banks (BUS). The glory of the Islamic banking industry in Indonesia was welcomed by various groups, both from the public and the government. The launch of the National Committee for Islamic Economics and Finance (KNEKS) in July 2017, has proven the government's partiality on Islamic financial institutions. As quoted by Kompas.com (2017), President Joko Widodo said that with the capital strength of the largest Muslim population in the world, Indonesia should be at the forefront, become the leader, and the center of the Islamic world finance.

Bank Muamalat, as a service company engaged in the banking industry, must always pay attention to the loyalty of its customers, so that customers do not switch to using services from other banks. Seeing the unique characteristics of service companies, Bank Muamalat must always maintain its image and service quality in order to increase trust and loyalty so as to avoid switching behavior from its customers. Customer loyalty is one crucial variable to be studied in the field of marketing, so it is widely used as an output variable by experts [1]-[5]. The high level of customer loyalty is effective marketing for a bank that is done through word of mouth (WOM) of customers to those closest to them. High loyalty from customers will also automatically reduce the likelihood of customers having switching behavior.

Research on antecedents of customer loyalty and switching intention has been carried out by experts such as customer satisfaction, switching costs, customer 
commitment, service quality, company reputation, and price [9]-[12]. Customer loyalty is defined as a strong desire from customers to buy back products or services and will not move to other companies [6]. The cause of customer loyalty must always be considered by the company, especially in the alternative conditions of many banks, such as in Indonesia. Seeing the competition between banks in Indonesia, which is very competitive, Bank Muamalat needs to identify factors that cause customers to become loyal. Based on previous research that has been done, there are several factors that determine the behavior of a bank's customers, such as service quality and switching costs.

Switching costs perceived by customers can be positive or negative. Positive switching costs can be in the form of bonuses and other benefits to customers and will increase customer loyalty, while negative switching costs such as penalties can reduce customer loyalty in Islamic banks [1], [13]. Tax et al. (2013) explains that the impact of negative switching costs in the form of penalties can cause emotions, attitudes, and behaviors that tend to be negative from customers. Given that in the banking industry, penalties are very often issued by banks to their customers [15]. For this reason, the main objective of this study is to develop and test some theories that discuss the effect of service quality and switching costs on customer loyalty in Bank Muamalat and their impact on switching intention.

In order to build a linking model of service quality and switching costs to customer switching intentions, researchers add a mediating variable that is able to explain the causal relationship. Researchers add the customer loyalty variable as the antecedent variable of switching intention, as well as the consequence variable, service quality, and switching cost. For this reason, service quality and switching costs built by the companies will reduce switching intention through increased customer loyalty. Companies need to maintain service quality and increase switching costs so that customers feel at a loss if they leave the company. The purpose of this study is to look at the role of customer loyalty, which connecting service quality and switching cost to switching intention.

\section{THEORY AND HYPOTHESIS}

\section{Service Quality and Customers' Loyalty}

Customers who feel served well, friendly and fast will be more loyal to the bank. Seeing the banking industry is one industry that requires excellent service, then service quality from banks must always be maintained in order to increase the trust of its customers. Previous research has proven the positive effect of service quality on customer loyalty [26]-[29]. From previous research, it can be interpreted that the better the service quality of a company, the more customer loyalty to continue to transact at the company. Based on a review of these theories and reasons, the researcher formulates the first hypothesis as follows:

Hypothesis 1: Service quality has a positive effect on customer loyalty

\section{Switching Costs and Customer Loyalty}

Switching cost is one of the company's strategies to create a barrier for a customer to move to other service providers. Some researchers find that switching costs is a corporate strategy in reducing the level of customer transition from one company to another [13], [30]. Customers who feel lost benefits or costs incurred when they switch to other service providers, then these customers are likely to continue to use the products and services of a company. Some researchers have proven the role of switching costs on customer loyalty [1], [13]. In other words, customer loyalty will increase if the switching costs created by a company are high. From this explanation, the second hypothesis can be formed as follows:

Hypothesis 2: Switching cost has a positive effect on customer loyalty

\section{Customer Loyalty with Switching Intention}

Bhat et al. (2018) explain that the banking industry is more vulnerable to having switching behavior. It takes an increase of customer loyalty in order to reduce the level of switching intention that results in switching behavior. This opinion is in line with some previous research, which states that customer loyalty has a negative effect on switching intention [33], [34]. Customers who are loyal to a company will not move to another company. It can be interpreted that loyal customers will continue to use the products and services of a company. However, there are other factors that require the customer to use the products and services of a company, including company policy where the customer works, distance, an invitation from friends or family to use products and services from the company, and impulse buying. For this reason, the researcher will try again to examine the effect of customer loyalty on switching intention. From this explanation, the researchers formulated the third hypothesis as follows:

Hypothesis 3: Customer loyalty has a negative effect on switching intention

\section{Mediating Role of Customers' Loyalty}

Service company activities that require production and consumption are done simultaneously are certainly different from manufacturing companies where customers do not need to know the process of making products from these companies. This unique business process demands service companies like Muamalat Bank to always maintain its service quality so that every customer who makes a transaction feels comfortable and 
loyal to Muamalat's bank, therefore the customer's intention to switch to using the services of another bank will decrease. In addition to service quality, which is the key to the success of a service company, switching costs also play an important role in increasing customer loyalty. By affecting the psychological of the customer and creating a condition of losing something if the customer moves using the services of another bank, switching costs can be a solution for Bank Muamalat in creating loyalty, which results in low intention to switch.

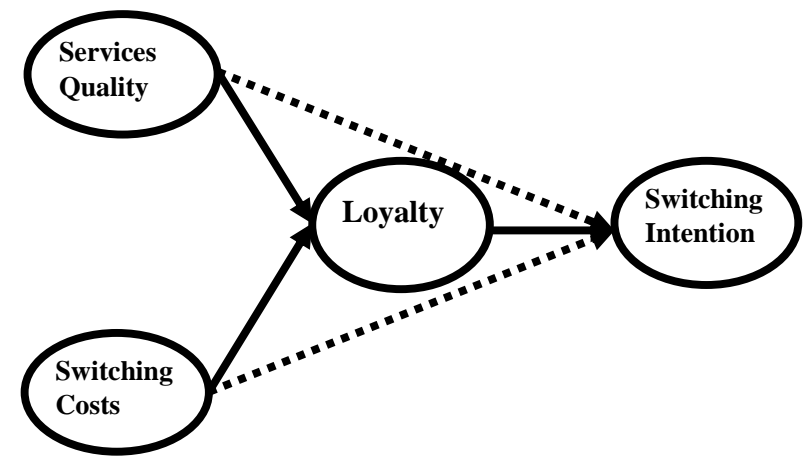

Figure 1. Research Model

Having an intention to switch is a consequence experience felt by customers in using the services of a company. Of course, it does not just happen but has gone through several stages. Intention to switch can be caused by poor service quality and low switching costs felt by customers, thereby reducing customer loyalty. For this reason, researchers place customer loyalty as a link between service quality and switching costs to customer switching intentions. Placement of loyalty as a mediating variable has been done by previous studies such as [35] that connect image and perceived quality to purchase intention. Mosavi et al. (2018) link customer satisfaction and trust in switching intention. Dikcius et al. (2019) linking satisfaction with behavioral loyalty, [38] linking brand equity, value equity, and relationship equity to WOM, [39] links social media marketing applications with purchase intentions. From the reasons above, the researcher formulates the hypothesis as follows:

Hypothesis 4: Customer loyalty mediates the effect of service quality with switching intention

Hypothesis 5: Customer loyalty mediates the effect of switching costs with switching intention

\section{METHODS}

\section{Sample and Procedures}

We collect data from customers of Bank Muamalat Indonesia, which is the first Sharia bank in Indonesia and one of the largest Sharia Banks in Indonesia through nonprobability sampling techniques. The questionnaire was distributed via offline and online and managed to collect 251 respondents consisting of 173 data online and 78 data offline. However, there were 25 respondents who did not complete the questionnaire, so there were $226(90.04 \%)$ questionnaire data that could be processed. The research data was then reduced again because there were 58 outlier data, so the final sample in this study was 168 respondents $(74.33 \%)$.

\section{Measurement}

Measurements in this study adopted previous research, and customers were asked to explain their perceptions about service quality, switching cost, loyalty, and switching intention as customers at Bank Muamalat Indonesia. For all variables in this study measured using a 5-point Likert scale, namely $1=$ strongly disagree and $5=$ strongly agree.

\section{Service Quality}

Service quality is the attitudes and perceptions of customers formed by the difference between the actual service quality they receive and the customer service quality expectations for the services of the bank [40]. Measuring instruments used to measure the level of customer perception of service quality banks using 24 statement items developed by Parasuraman et al. (1985) and Othman \& Owen (2001). The measurement dimensions are Compliance, Assurance, Reliability, Tangibility, Empathy, and Responsiveness (CARTER). An example of an item of the statement is "Islamic banks in accordance with Islamic law and principles." Cronbach alpha (0.911).

\section{Switching Cost}

Burnham et al. (2003) describes switching costs as costs incurred to move from a service provider that is used now to a new service provider. To measure the switching costs of Muamalat bank customers, we use an indicator developed by Han et al. (2011) consisting of 5 statement items. An example of a statement item is "There are many incentives that I will not get if I switch to another bank". Cronbach alpha (0.862).

\section{Customers' Loyalty}

Customer loyalty is a firm intention from customers to repurchase products or services from a company and will not move to another company [6]. To measure the loyalty of Bank Muamalat customers, we use 7 statement items developed by [5]. An example of the statement is, "I rarely think about switching to another bank service". Cronbach alpha (0.936).

\section{Switching Intention}

Oliver (1997), in [8], defines switching intention as an affirmation of one's desire to move from the current service provider to another service provider. Measuring instruments used to measure the level of switching intention of customers using five items statement developed by [10]. An example of his statement is, "I will 
switch to another bank that offers better returns". Cronbach alpha (0.950).

\section{RESULT}

\section{Confirmatory Factor Analysis}

We tested it three times to see discriminant validity because the first and second tests still contained items that had a loading factor $<70$, so the items had to be reduced. As for the total of 41 initial questionnaire items, we reduced 20 items, so that the remaining 21 questionnaire items.

\section{Hypotheses Testing}

Before conducting hypothesis testing, we assessed the Goodness of Fit (GOF) model using the Maximum Likelihood (ML) method using AMOS Software. The results of testing the GOF model in this study is quite good because the value of each fit test meets the assumption of SEM usage.

Hypothesis testing in this study is intended to answer research questions by analyzing the structural model. Structural analysis in this study can be seen from the value of standardized regression weight, which explains the coefficient of influence between variables. The explanation of the causal relationship from this study can be seen in the following Table 1 .

Table 1. Hypotheses testing

\begin{tabular}{|l|l|l|l|l|l|l|}
\hline & & & Estimation & S.E. & C.R. & $p$ \\
\hline LOY & $<---$ & SQ & 0.467 & 0.114 & 4.084 & 0.000 \\
\hline LOY & $<---$ & SC & 0.439 & 0.080 & 5.471 & 0.000 \\
\hline SI & $<---$ & LOY & -1.097 & 0.295 & -3.722 & 0.000 \\
\hline SI & $<---$ & SQ & 0.448 & 0.246 & 1.820 & 0.069 \\
\hline SI & $<---$ & SC & 0.236 & 0.201 & 1.173 & 0.241 \\
\hline
\end{tabular}

Primary Data (2020)

Table 2. Sobel Test (SQ-LOY-SI)

\begin{tabular}{|c|c|c|c|c|}
\hline Input: & & Test statistic: & Std. Error: & $p$-value: \\
\hline a 0.467 & Sobel test: & -2.75339259 & 0.18606101 & 0.00589811 \\
\hline b -1.097 & Aroian test: & -2.7094894 & 0.18907585 & 0.00673869 \\
\hline$s_{\mathrm{a}} 0.114$ & Goodman test: & -2.79950152 & 0.18299651 & 0.00511816 \\
\hline$s_{b} 0.295$ & Reset all & & Calculate & \\
\hline
\end{tabular}

Table 3. Sobel Test (SC-LOY-SI)

\begin{tabular}{|c|c|c|c|c|}
\hline Input: & & Test statistic: & Std. Error: & $p$-value: \\
\hline a 0.439 & Sobel test: & -3.07839486 & 0.15643965 & 0.00208119 \\
\hline b -1.097 & Aroian test: & -3.04395287 & 0.15820974 & 0.00233492 \\
\hline$s_{\mathrm{a}} 0.080$ & Goodman test: & -3.11403307 & 0.15464929 & 0.00184549 \\
\hline$s_{b} 0.295$ & Reset all & & Calculate & \\
\hline
\end{tabular}

From the results of testing the hypotheses in Table 1 above, it is known that the regression coefficient effect of service quality on loyalty is $(\beta=0.467$; C.R. $=4.084 ; p$ $<0.050)$ which shows that service quality has a positive effect on loyalty. It indicates support for the first hypothesis, which says that service quality has a positive effect on loyalty. This means that the better service quality provided by Muamalat Bank employees will increase customer loyalty.

From the results of testing the hypotheses in Table 1 above, it is known that the regression coefficient effect of switching cost on loyalty is $(\beta=0.439$; C.R. $=5.471 ; \mathrm{p}$ $<0.050$ ) which shows the switching cost has a positive effect on loyalty. It provides support for the second hypothesis, which explains that switching costs have a positive effect on loyalty. This means that the higher the customer feels the switching cost provided by Muamalat bank, the higher the loyalty of the customer.

From the results of testing the hypotheses in Table 1 above, it is known that the regression coefficient effect of loyalty on switching intention is $(\beta=-1.097$; C.R. $=$ 3.772; $\mathrm{p}<0.050$ ) which shows that loyalty has a negative effect on switching intention. It provides support for the third hypothesis, which explains that loyalty has a negative effect on switching intention. This means that the higher the loyalty level of Bank Muamalat's customers, the lower the customer's intention to switch to using another bank's services.

From the results of testing the hypothesis by comparing direct effects with indirect effects, it shows that the value of indirect effects is greater than the direct effects $(0.242<0.277)$. In addition, the tests using the Sobel test shown in table 2 above, note that the value of t-count or C.R. of the service quality effect on switching intention through loyalty is $-2,753$ with a significance level of .050 .05 which indicates that loyalty mediates the effect of service quality on switching intention. The results of testing the hypothesis provide support for the fourth hypothesis, which explains that loyalty mediates the effect of service quality on switching intention. The role of loyalty in this influence is full mediation, which means that the effect of service quality variables on switching intention must pass through loyalty. This is shown in Table 1 , where the effect of service quality on switching intention is not directly significant $(\beta=0.448$; C.R. $=1,820 ; p>0.050)$, so it must first pass through loyalty.

From the results of testing the hypothesis by comparing the direct effects with indirect effects shows that the value of indirect effects is greater than the direct effects $(0.189<0.386)$. In addition, tests using the Sobel test shown in table 3 above, note that the value of t-count or C.R. of the switching cost effect on switching intention through loyalty is $-3,078$ with a significance level of .050 .05 which indicates that loyalty mediates the effect of switching costs on switching intention. These provide 
support for the fifth hypothesis, which explains that loyalty mediates the effect of switching costs on switching intention. The role of loyalty in this effect is full mediation, which means the influence of switching cost variables on switching intention must pass through loyalty. This is shown in Table 1, where the effect of switching costs on switching intention is not directly significant $(\beta=0.236 ;$ C.R. $=1.173 ; p>0.050)$, so it must pass through loyalty first.

\section{DISCUSSION}

The results of hypothesis testing in this study indicate that service quality has a positive effect on customer loyalty. This can be proven from the estimated value of 0.467 and the value of C.R 4.084 with a p-value $<0.05$, which indicates there is a positive effect on service quality on customer loyalty. It can be said that the better the service quality provided by Bank Muamalat Indonesia employees, the higher the loyalty of its customers. Customers who feel comfortable, safe, and are well served in every financial service transaction process at Bank Mumalat Indonesia will feel bound and tend to convey positive things about the bank to others.

This research confirms the Social Exchange Theory, which explains that a person will provide compensation in accordance with what he receives. In this case, customers who get good service from Bank Muamalat Indonesia will respond by becoming loyal towards Bank Muamalat Indonesia. This research supports Signaling Theory, which explains that the company will show the attributes/capabilities it has in this case of good service in order to improve the company's image and satisfaction in the eyes of customers. This study also supports previous research, which says service quality has a positive influence on customer loyalty [27], [42], [43].

The results of testing the second hypothesis in this study indicate that switching costs have a positive influence on customer loyalty. This can be proven from the estimated value of 0.439 and the magnitude of the value of C.R 5.471 with $\mathrm{p}$-value $<0.05$, which indicates there is a positive effect of switching costs on customer loyalty. It can be said that the greater the customer feels the switching cost of Bank Muamalat Indonesia, the higher the loyalty of Bank Muamalat Indonesia's customers. Customers who lose value or feel loss if they switch to using other bank services, will feel bound and tend to continue to use that bank services.

Switching cost is one of the company strategies to bind customers so as not to switch to using the services of other companies. Switching costs are not only costs incurred economically, but psychological conditions that are less comfortable such as psychological attachment and loss of benefits, are also costs that must be paid by customers if they switch to other service providers. Seeing the increasing number of banking institutions and the intense competition between banks in Indonesia, switching costs are an alternative competitive strategy that needs to be considered by banking institutions to maintain customer loyalty. High switching costs make customers think seriously about leaving the services of the bank.

This research successfully explains Reinforcement Theory that someone will act to get something they want and avoid something they don't want. The theory of Planned Behavior also explains that a person's behavior is formed from attitudes towards behavior, behavior control, and social norms so that if switching costs are considered large, it will affect one's behavior in acting [44]. In this case, Bank Muamalat Indonesia's customers will continue to use the services of the bank, when they feel disadvantaged if they switch to using the services of another bank. This research is supported by other empirical research, which says that switching costs have a positive effect on customer loyalty [1], [13], [42]

The results of testing the third hypothesis in this study indicate that loyalty has a negative effect on switching intention. It can be proven from the estimated value of 1,097 and the magnitude of the value of C.R-3,722 with p-value $<0.05$, which indicates there is a negative effect of loyalty on the customer's switching intention. It can be said that the higher the customer loyalty of Bank Muamalat Indonesia, the lower the switching intention of Bank Muamalat Indonesia customers. Customers who feel attached to Bank Muamalat Indonesia tend not to think about switching to using the services of other banks.

Customer loyalty, which is the ultimate goal of bank marketing, is considered to be able to increase profits for Bank Muamalat Indonesia. Customers who have high loyalty can become endorsers of a company by saying positively about the bank. Loyal customers also tend to be more tolerant of the mistakes made by a company, so loyalty is the key to reducing the company's switching intention [45], [46]. The results of this study support previous research, which says that loyalty has a negative effect on customer switching intention [33], [34], [36].

Sobel test results in this study indicate that loyalty can mediate the effect of service quality on customer switching intentions. It can be proven from the statistical test (C.R.) value of -2.753 with p-value $<0.05$, which shows that loyalty can mediate the effect of service quality on customer switching intentions. It can be said that the effect of service quality on switching intention must be through customer loyalty. Customers who feel comfortable, safe, and well served by Muamalat Indonesia bank employees will increase customer loyalty, which will lead to decreased switching intention of the customer. Direct and indirect effects test results also show that loyalty fully mediates the effect of service quality on customer switching intentions. This is 
evidenced by the value of indirect effects, which is greater than direct effects $(0.242<0.277)$

This study proves that customer intentions to take action can be predicted and shaped by companies through external stimuli, such as providing good service so that it has an impact on loyalty and leads to low switching intention. Low switching intention from the customer is certainly an achievement for a bank, especially if the customer is a priority customer who gives a lot of benefits to the bank. The low switching intention also shows that the service quality provided by Bank Muamalat Indonesia can be said to meet customer expectations. This research can be explained by Social Exchange theory, which explains that customers who get good services from Bank Muamalat Indonesia will respond by being loyal so that the switching intention of these customers will decrease.

The Sobel test results in this study indicate that loyalty can mediate the effect of switching costs on customer switching intentions. It can be proven from the statistical test (C.R.) value of -3.078 with $p$-value $<0.05$, which indicates that loyalty can mediate the effect of switching costs on customer switching intentions. It can be said that the effect of switching costs on switching intention must be through customer loyalty. Customers who feel compelled to pay or lose benefits if leaving the services of Bank Muamalat Indonesia will tend to remain at Bank Muamalat Indonesia, so as to reduce the switching intention of these customers. Direct and indirect effects test results also show that loyalty fully mediates the effect of switching costs on customer switching intentions. This is evidenced by the value of indirect effects, which is greater than direct effects $(0.189$ $<0.386)$

This research shows that Bank Muamalat Indonesia customers tend to avoid losses that arise when they switch rather than start to use the services of other banks. From the high switching cost felt by these customers, it makes Bank Muamalat Indonesia's customers tend to be loyal, which leads to low switching intention. Losing the benefits gained while being a customer of Bank Muamlaat Indonesia is also a bank strategy to reduce switching intention through loyalty. For this reason, Bank Muamalat Indonesia needs to increase the benefits obtained by customers, so that customers will feel disadvantaged if they switch to using services from other banks. This study also supports previous research, which explains that loyalty mediates the effect of switching costs on customer switching intentions [9].

\section{MANAGERIAL IMPLICATION}

The results of this study can be considered by the Bank Muamalat Indonesia, especially in terms of minimizing losses due to high switching behavior. High switching intention can indicate low customer loyalty caused by the bank services not in accordance with customer expectations. In addition, the role of switching costs needs to be considered to increase customer loyalty, which can weaken customer switching intention. For this reason, Bank Muamalat Indonesia must always maintain service quality and increase switching costs regularly so that customer loyalty can increase.

\section{CONCLUSION}

This study corroborates previous research that succeeded in making customer loyalty as a mediating variable to the effect of independent variables on the dependent variable. Loyalty is one of the strong predictors in explaining customer switching intentions. This research succeeded in proving the role of service quality and switching cost can weaken customer switching intention through customer loyalty. The results of this study also reinforce the social exchange theory and reinforcement theory that explain individual behavioral intention in decision making.

\section{LIMITATION AND FUTURE RESEARCH}

recommendations for further research. Weaknesses in this research are that there may be a common method bias because the use of self-reported methods and online questionnaires is possible that there is a bias in respondent answers. In addition, the selection of switching cost variables is not appropriate because customers can choose more than one banking service so that customers do not need to switch. Besides, banking services have almost the same quality from one another, and it makes it difficult for customers to identify the switching costs owned by a bank with another bank.

\section{REFERENCES}

[1] B. R. Hoyt, T. McCullough, E. Callihan, and A. Van Bibber, "the Impact of Cause Related Marketing on Customer Loyalty: a Case Study on Cause Fit and Switching Barriers for Retail Banks.," Int. J. Business, Mark. Decis. Sci., vol. 8, no. 1, pp. 1-21, 2015, [Online]. Available: http://escweb.lib.cbs.dk/login?url=http://search.ebscohost.co $\mathrm{m} /$ login.aspx ?direct $=$ true $\& \mathrm{db}=\mathrm{bth} \& \mathrm{AN}=11194794$ $6 \&$ site $=$ ehost-live $\&$ scope $=$ site.

[2] S. A. Taylor, L. A. N. Donovan, and C. Ishida, "Consumer Trust and Satisfaction in the Formation of Consumer Loyalty Intentions in Transactional Exchange: The Case of a Mass Discount Retailer," J. Relatsh. Mark., vol. 13, no. 2, pp. 125-154, 2014, doi: 10.1080/15332667.2014.910076.

[3] M. Rafiq, H. Fulford, and X. Lu, "Building customer loyalty in online retailing: The role of relationship quality," J. Mark. Manag., vol. 29, no. 
3-4, pp. 494-517, 2013, doi: 10.1080/0267257X.2012.737356.

[4] A. Osarenkhoe and M. B. Komunda, "Redress for Customer Dissatisfaction and Its Impact on Customer Satisfaction and Customer Loyalty," J. Mark. Dev. Compet., vol. 7, no. 2, pp. 102-114, 2013.

[5] R. E. Anderson and S. Swaminathan, "Customer satisfaction and loyalty in e-markets: A PLS path modeling approach," J. Mark. Theory Pract., vol. 19, no. 2, pp. 221-234, 2011, doi: 10.2753/MTP1069-6679190207.

[6] R. L. Oliver, "1999 Oliver whence consumer loyalty.pdf," J. Mark., vol. 63, no. Special Issue 1999, pp. 33-44, 1999.

[7] K. Z. K. Zhang, C. M. K. Cheung, and M. K. O. Lee, "Online service switching behavior: The case of blog service providers," J. Electron. Commer. Res., vol. 13, no. 3, pp. 184-197, 2012.

[8] H. Han, W. Kim, and S. S. Hyun, "Switching intention model development: Role of service performances, customer satisfaction, and switching barriers in the hotel industry," Int. J. Hosp. Manag., vol. 30, no. 3, pp. 619-629, 2011, doi: 10.1016/j.ijhm.2010.11.006.

[9] P. Thaichon and T. N. Quach, "Integrated Marketing Communications and Their Effects on Customer Switching Intention," J. Relatsh. Mark., vol. 15, no. 1-2, pp. 1-16, 2016, doi: 10.1080/15332667.2014.965647.

[10] F. Mohsan, M. M. Nawaz, M. S. Khan, Z. Shaukat, and N. Aslam, "Impact of customer satisfaction on customer loyalty and intentions to switch : evidence from banking sector of Pakistan," Int. J. Bus. Soc. Sci., vol. 2, no. 16, pp. 263-270, 2011.

[11] A. Saeed, N. Hussain, and A. Riaz, "Factors affecting consumers' switching intentions," Eur. J. Soc. Sci., vol. 19, no. 1, pp. 54-61, 2011.

[12] M. D. Clemes, C. Gan, and D. Zhang, "Customer switching behaviour in the Chinese retail banking industry," Int. J. Bank Mark., vol. 28, no. 7, pp. 519546, 2010, doi: 10.1108/02652321011085185.

[13] D. Pick and M. Eisend, "Customer responses to switching costs: A meta-analytic investigation of the moderating influence of culture," J. Int. Mark., vol. 24, no. 4, pp. 39-60, 2016, doi: 10.1509/jim.15.0139.

[14] S. S. Tax, Y. S. Kim, and S. Nair, "Getting the right payoff from customer penalty fees," Bus. Horiz., vol. 56, no. 3, pp. 377-386, 2013, doi: 10.1016/j.bushor.2013.01.012.

[15] E. H. Fram and A. Callahan, "Do you know what the customer you penalized yesterday is doing today? A pilot analysis," J. Serv. Mark., vol. 15, no. 6, pp. 496-509, 2001, doi: 10.1108/EUM0000000006102.

[16] H. Jack Walker, T. N. Bauer, M. S. Cole, J. B. Bernerth, H. S. Feild, and J. C. Short, "Is this how I will be treated? Reducing uncertainty through recruitment interactions," Acad. Manag. J., vol. 56, no. 5, pp. 1325-1347, 2013, doi: 10.5465/amj.2011.0196.

[17] S. P. Robbins and T. A. Judge, Organizational behaviour London, Pearson. London: Pearson, 2016.

[18] V. Đkudienë, Đ. Èertokas, D. McCorkle, and J. Reardon, "the Effect of E-Shops' Service Quality on Lithuanian Consumers' Purchase Intentions.," Int. J. Business, Mark. Decis. Sci., vol. 8, no. 1, pp. 43-59, 2015, [Online]. Available: http://search.ebscohost.com/login.aspx?direct=true $\& \mathrm{db}=\mathrm{bth} \& \mathrm{AN}=111947949 \&$ lang $=$ it \&site=ehostlive.

[19] R. C. Maysami, V. P. Goby, and E. C. Mensah, "Enhanced customer satisfaction in the wake of banking liberalization: the Singaporean case," Int. J. Business, Mark. Decis. Sci., vol. 7, no. 1, pp. 1-18, 2014.

[20] R. Casidy, "Linking Brand Orientation with Service Quality, Satisfaction, and Positive Word-of-Mouth: Evidence from the Higher Education Sector," $J$. Nonprofit Public Sect. Mark., vol. 26, no. 2, pp. 142-161, 2014, doi: 10.1080/10495142.2014.901004.

[21] P. Bawa, B. L. Gupta, and B. Sharma, "Retail Service Quality's Impact on Value Delivery \& Customer Satisfaction in a Retail Store Environment," vol. 9, no. 1, pp. 37-44, 2013.

[22] S. Chawla and R. Sehgal, "An Empirical Analysis of the Awareness and Satisfaction Level of Internet Banking Users with Respect to Demographic Profile,” IUP J. Mark. Manag., vol. XI, no. 1, 2012.

[23] A. Parasuraman, V. A. Zeithaml, and L. L. Berry, "A Conceptual Model of Service Quality and Its Implications for Future Research," J. Mark., vol. 49, no. 4, p. 41, 1985, doi: 10.2307/1251430.

[24] M. Othman and H. L. Owen, "Managing and Measuring Customer Service Quality in Islamic Banks: A Study of the Kuwait Finance House," Int. J. Islam. Financ. Serv., vol. 3, no. 1, pp. 1-26, 2001, doi: 10.3366/edinburgh/9780748621002.003.0005. 
[25] V. A. Zeithaml, L. L. Berry, and A. Parasuraman, "The behavioral consequences of service quality," $J$. Mark., vol. 60, no. 2, pp. 31-46, 1996, doi: $10.2307 / 1251929$.

[26] M. Srivastava and A. K. Rai, “An investigation into service quality-customer loyalty relationship: the moderating influences," Decision, vol. 41, no. 1, pp. 11-31, 2014, doi: 10.1007/s40622-014-0025-5.

[27] M. F. Diallo, F. Diop-Sall, S. Djelassi, and D. Godefroit-Winkel, "How Shopping Mall Service Quality Affects Customer Loyalty Across Developing Countries: The Moderation of the Cultural Context," J. Int. Mark., vol. 26, no. 4, pp. 69-84, 2018, doi: 10.1177/1069031X18807473.

[28] C. V. Priporas, N. Stylos, L. N. Vedanthachari, and P. Santiwatana, "Service quality, satisfaction, and customer loyalty in Airbnb accommodation in Thailand," Int. J. Tour. Res., vol. 19, no. 6, pp. 693704, 2017, doi: 10.1002/jtr.2141.

[29] S. C. Li, "Exploring the Relationships among Service Quality, Customer Loyalty and Word-OfMouth for Private Higher Education in Taiwan," Asia Pacific Manag. Rev., vol. 18, no. 4, pp. 375389, 2013, doi: 10.6126/APMR.2013.18.4.02.

[30] V. Gautam, "Linkages Between Switching Barriers and Service Recovery Evaluation: An Indian Exploration," J. Glob. Mark., vol. 26, no. 3, pp. 147-154, 2013, doi: 10.1080/08911762.2013.805859.

[31] R. C. Martins, L. F. Hor-Meyll, and J. B. Ferreira, "Factors affecting mobile users' switching intentions: A comparative study between the Brazilian and German markets," BAR - Brazilian Adm. Rev., vol. 10, no. 3, pp. 239-262, 2013, doi: $10.1590 / \mathrm{S} 1807-76922013000300002$.

[32] D. Nikbin, I. Ismail, M. Marimuthu, and H. Armesh, "Perceived justice in service recovery and switching intention: Evidence from Malaysian mobile telecommunication industry," Manag. Res. Rev., vol. 35, no. 3-4, pp. 309-325, 2012, doi: $10.1108 / 01409171211210181$.

[33] S. A. Bhat, M. A. Darzi, and S. H. Parrey, "Antecedents of Customer Loyalty in Banking Sector: A Mediational Study," Vikalpa, vol. 43, no. 2, pp. 92-105, 2018, doi: $10.1177 / 0256090918774697$.

[34] S. H. Lee and K. S. Jung, "Loyal customer behaviors: Identifying brand fans," Soc. Behav. Pers., vol. 46, no. 8, pp. 1285-1303, 2018, doi: 10.2224/SBP.6482.
[35] C. Calvo-Porral, V. A. Martínezfernández, and O. Juanatey-Boga, "Influence of manufacturer signature on store brands' loyalty and purchase intention," RAE Rev. Adm. Empres., vol. 56, no. 1, pp. 29-42, 2016, doi: 10.1590/S0034759020160104

[36] S. M. Mosavi, M. S. Sangari, and A. Keramati, “An integrative framework for customer switching behavior," Serv. Ind. J., vol. 38, no. 15-16, pp. 1067-1094, 2018, doi: $10.1080 / 02642069.2018 .1428955$.

[37] V. Dikcius, S. Kirse, R. Casas, and A. Koncanina, "Drivers of attitudinal and behavioural loyalty in B2-B markets," Eng. Econ., vol. 30, no. 1, pp. 94 102, 2019, doi: 10.5755/j01.ee.30.1.20182.

[38] M. R. Karimi Alavijeh, A. Esmaeili, A. Sepahvand, and V. Davidaviciene, "The effect of customer equity drivers on word-of-mouth behavior with mediating role of customer loyalty and purchase intention," Eng. Econ., vol. 29, no. 2, pp. 236-246, 2018, doi: 10.5755/j01.ee.29.2.17718.

[39] A. Ceyhan, "The Impact of Perception Related Social Media Marketing Applications on Consumers' Brand Loyalty and Purchase Intention," EMAJ Emerg. Mark. J., vol. 9, no. 1, pp. 88-100, 2019, doi: 10.5195/emaj.2019.173.

[40] K. Bahia and J. Nantel, "A reliable and valid measurement scale for the perceived service quality of banks," Int. J. Bank Mark., vol. 18, no. 2, pp. 8491, 2000, doi: 10.1108/02652320010322994.

[41] T. A. Burnham, J. K. Frels, and V. Mahajan, "Customer switching costs: A typology, antecedents and consequences," J. Acad. Mark. Sci., vol. 31, no. 2, pp. 109-126, 2003

[42] F. Quoquab, N. L. Abdullah, and J. Mohammad, "Investigating the effects of consumer innovativeness, service quality and service switching costs on service loyalty in the mobile phone service context," Gadjah Mada Int. J. Bus., vol. 18, no. 1, pp. 21-53, 2016, doi: 10.22146/gamaijb.9286.

[43] M. V. Ngo and H. H. Nguyen, "The Relationship between Service Quality, Customer Satisfaction and Customer Loyalty: An Investigation in Vietnamese Retail Banking Sector," J. Compet., vol. 8, no. 2, pp. 103-116, 2016, doi: 10.7441/joc.2016.02.08.

[44] P. Jadmiko, "Linking Perceived Social Support To Social Entrepreneurial Intention: the Mediating Role of Attitude Becoming Social Entrepreneur," vol. 6, no. 2, pp. 52-60, 2020, [Online]. Available: https://www.jurnal.umsb.ac.id/index.php/menaraek 
onomi/article/download/1844/pdf\%0Ahttps://www. jurnal.umsb.ac.id/index.php/menaraekonomi/article /view/1844\%0Ahttps://lens.org/069-380-243-063526.

[45] M. Zakiy, "The Moderating Effect Of Switching Cost On The Influence Of Price And Service Quality Towards Switching Intention," vol. 353, no. IcoSIHESS, pp. 161-167, 2019, doi: 10.2991/icosihess-19.2019.27.

[46] M. Z. Ishak and E. P. Azzahroh, "Pengaruh Kualitas Layanan Terhadap Loyalitas Nasabah Bank Syariah Dengan Kepuasan Nasabah Sebagai Variabel Intervening," J. Ekon. dan Bisnis Islam (Journal Islam. Econ. Business), vol. 3, no. 1, p. 26, 2017 , doi: 10.20473/jebis.v3i1.3599. 